\title{
CLIMATE CHANGE IMPACT ON THE HUMAN RIGHT TO ENVIRONMENTAL CONDITIONS OF A SPECIFIED QUALITY (SAFE, CLEAN, HEALTHY AND SUSTAINABLE ENVIRONMENT): SOME INTERNATIONAL AND UKRAINIAN ENVIRONMENTAL LAW ISSUES
}

\author{
Olha Sushyk*, Olena Shompol ${ }^{*}$
}

\begin{abstract}
This article discusses recognition between climate change and human rights at the international level. The analysis shows that despite the fact that the UN climate change framework does not adequately address the magnitude of the threat posed by climate change related harm to human rights, domestic, regional or international courts must take account of its provisions in deciding cases. The article argues that the causes for climate cases are diverse, whereby the most often ones are those referring to the competent public authority's failure to fulfil its obligation to regulate limitations of greenhouse gas (GHG) emissions. Identification of the links between human rights and environmental protection, were apparent at least from the first international conference on the human environment, held in Stockholm in 1972. More broadly, it demonstrates international environmental agreements, were some aspects of the right to environmental conditions of a specified quality are identified. This article discusses also theoretical issues of individual environmental rights and the right to environmental safety in Ukraine.
\end{abstract}

Key words: climate, human rights, environmental, Ukraine

Ph.D. in Law, Associate Professor of the Department of Environmental Law of the Faculty of Law at the Taras Shevchenko National University of Kyiv Ukraine; o.sushyk@ gmail.com

** Ph.D. in Law, Associate Professor of the Department of Environmental Law of the Faculty of Law at the Taras Shevchenko National University of Kyiv Ukraine; shompol. ekopravo@gmail.com 


\section{INTRODUCTION}

Climate change has become one of the most serious challenges of our time. The global climate has changed relative to the pre-industrial period, and there is a lot of evidence that these changes have had dangerous impacts on ecosystems and human well-being. Climate-related risks for natural and human systems are higher for global warming of $1.5^{\circ} \mathrm{C}$ than at present, but lower than at $2^{\circ} \mathrm{C}$ (high confidence). These risks depend on the magnitude and rate of warming, geographic location, levels of development and vulnerability, and on the choices and implementation of adaptation and mitigation options ${ }^{1}$. Transnational impacts on natural and human systems from global warming have already been observed. Greenhouse gases spread beyond the boundaries of the state and contamination in one country can cause damage to another, which is thousands of kilometres away, threatening human rights around the world. In particular, deforestation in Ukraine can cause difficult situation across the whole Europe, since forests take on the role of carbon sinks, and thus affect the well-being of people living outside the country in which they are located. Moreover, it is equally important that due to sea-level rise citizens of small island developing states (eg. Maldives, Seychelles, the Dominican Republic, Fiji, Palau, etc.) are forced to move from their native homes, which requires coordinated international actions to protect their rights. In light of the foregoing, the issues of the negative impact of climate change on humans and their right to a good environment has been increasing.

Climate change impact on human rights

The issues of interaction between climate changes and human rights were raised in international resolutions, decisions and reports. For the first time in 2008, the UN Human Rights Council (thereafter - UNHRC) in Resolution 7/23 "Human Rights and Climate Change" determines "climate change poses an immediate and far-reaching threat to people and

1 „An IPCC Special Report on the impacts of global warming of $1.5^{\circ} \mathrm{C}$ above pre-industrial levels and related global greenhouse gas emission pathways, in the context of strengthening the global response to the threat of climate change, sustainable development, and efforts to eradicate poverty", 7, May 20, 2019 https://report.ipcc.ch/sr15/pdf/ sr15_spm_final.pdf 
communities around the world and has implications for the full enjoyment of human rights" 2 and in 2009 UNHRC adopted both direct and indirect, for the effective enjoyment of human rights including, inter alia, the right to life, the right to adequate food, the right to the highest attainable standard of health, the right to adequate housing, the right to self-determination and human rights obligations related to access to safe drinking water and sanitation, and recalling that in no case may a people be deprived of its own means of subsistence" ${ }^{3}$. In 2010, the Conference of the Parties to the United Nations Framework Convention on Climate Change (thereafter - UNFCCC) adopted a decision quoting the statements in Human Rights Council resolution 10/4 that the adverse effects of climate change have a range of implications for the effective enjoyment of human rights and that the effects will be felt most acutely by those segments of the population that are already vulnerable ${ }^{4}$.

The 2014 UN Intergovernmental Panel on Climate Change (thereafter - UN IPCC) also predicted that the effects of climate change would be serious, widespread and irreversible 5 . This report confirms that climate change is caused by anthropogenic emissions of greenhouse gases. Among other impacts, climate change negatively affects human's rights. The right to life, which is a prerequisite for all other human rights, poses threat to the systemic risks resulted from extreme weather events. Injuries, illnesses and fatalities will be caused by more intense heat waves and forest fires. Compliance with the right to health will be undermined by increased risks associated with foodborne, waterborne and vector diseases. The right to food will be also threatened, since climate changes will result in a decline in agricultural productivity. The UN IPCC also predicted that hundreds of

2 “Human Rights Council Resolution 7/23", 1, May 20, 2019 http://ap.ohchr.org/ documents/E/HRC/resolutions/A_HRC_RES_7_23.pdf

3 "Human Rights Council Resolution 10/4", 1, May 20, 2019 https://ap.ohchr. org/documents/E/HRC/resolutions/A_HRC_RES_10_4.pdf

4 David R. Boyd, "Statement on the human rights obligations related to climate change, with a particular focus on the right to life", 3, May 20, 2019 https://www.ohchr. org/Documents/Issues/Environment/FriendsIrishEnvironment25Oct2018.pdf

5 An IPCC Report "Climate Change 2014. Impacts, Adaptation, and Vulnerability Part A: Global and Sectoral Aspects”, 17-20, May 20, 2019 https://www.ipcc.ch/site/assets/uploads/2018/03/ar5_wgII_spm_en-1.pdf 
millions of people would be removed due to loss of land caused by coastal and inland waters, with a high risk of loss of vital activities in low-lying coastal areas and small insular islands due to sea levels rise and storm impacts.

Resolution 38/4 UNHRC on July 5, 2018 recognizes that women and girls are disproportionately affected by the negative impacts of climate change, and emphasizing that sudden-onset natural disasters and slow onset events seriously affect their access to food and nutrition, safe drinking water, sanitation, health-care services and medicines, education and training, adequate housing and access to decent work ${ }^{6}$.

Viewed cumulatively these impact represent environmental challenge on a scale not previously encountered and demanding serious long term and sincere commitment and cooperation from all nations ${ }^{7}$.

Unfortunately, the UN Climate Change International Legal Regime does not pay enough attention to the interaction between climate changes and human rights. The Framework Convention on Climate Change (UNFCCC) $(1992)^{8}$, in its Article 1, defines climate change as: "a change of climate which is attributed directly or indirectly to human activity that alters the composition of the global atmosphere and which is in addition to natural climate variability observed over comparable time periods." The UNFCCC thus makes a distinction between climate change attributable to human activities and climate change that is not related to human activity. UNFCCC establishes in Art. 2 "stabilization of greenhouse gas concentrations in the atmosphere at a level that would prevent dangerous anthropogenic interference with the climate system ... within a time frame sufficient to allow ecosystems to adapt naturally to climate change'”. This objectives of the UNFCCC should be considered in the light of 1 paragraph of the Preamble, which reads "change in the Earth's climate and its adverse effects are a common concern of humankind'. The "adverse effects"

6 "Human Rights Council Resolution 38/4", 3, May 20, 2019. https://documents-dds-ny.un.org/doc/UNDOC/LTD/G18/201/26/PDF/G1820126.pdf?OpenElement

Bridget Lewis Environmental Human Rights and Climate Change. Current Status and Future Prospects, Singapore : Springer, 2018, 250.

8 United Nations Framework Convention on Climate Change and all other international agreement, which use in this article you may find on the official website of the UN May 20, 2019 https://documents.un.org/prod/ods.nsf/home.xsp 
refers to changes in the physical environment or biota resulting from climate change which have significant deleterious effects on the composition, resilience or productivity of natural and managed ecosystems or on the operation of socio-economic systems or on human health and welfare? UNFCCC identifies that States commit to taking precautionary measures to achieve the ultimate objective, in accordance with the principle of "common but differentiated responsibilities and respective capabilities". These provisions served as a basis for the adoption of the Kyoto Protocol to the UNFCCC dd. December 11, 1997, which establishes legally binding targets for emission reduction set for developed countries, based on a target reduction.

The first international legal climate change treaty that refers to human rights is the Paris Agreement (2015), which acknowledges that climate change is a common concern of humanity. The Preamble of the Paris Agreement provides as follows: Parties should, when taking action to address climate change, respect, promote and consider their respective obligations on human rights, the right to health, the rights of indigenous peoples, local communities, migrants, children, persons with disabilities and people in vulnerable situations and the right to development, as well as gender equality, empowerment of women and intergenerational equity (11 paragraph). Almost immediately thereafter, the Preamble notes: the importance of ensuring the integrity of all ecosystems, including oceans, and the protection of biodiversity, recognized by some cultures as Mother Earth, and noting the importance for some of the concept of 'climate justice', when taking action to address climate change. In addition, other paragraphs of the Preamble refer to that climate change actions, responses and impacts have with "equitable access to sustainable development and the eradication of poverty", "safeguarding food security and ending hunger" and "transition of the workforce and the creation of decent work and quality jobs". It thereby indirectly referrers to a right to sustainable development, as well as the right to food and labour rights.

9 "Adverse effects of climate change" are defined in Article 1 UNFCCC as changes in the physical environment or biota resulting from climate change which have significant deleterious effects on the composition, resilience or productivity of natural and managed ecosystems or on the operation of socio-economic systems or on human health and welfare. 
The Paris Agreement is the first legally binding multilateral climate instrument that mentions human rights, but does so in the Preamble and not in the operative part of the text ${ }^{10}$. A Savaresi provides that the Agreement provided a marginal victory for those advocating for building bridges between the climate regime and human rights law ${ }^{11}$.

In an important sense, the Paris Agreement also contains articles, which indirectly affect the human rights of forest dwellers (art.5) and the inhabitants of small island developing states (SIDS), among whom are substantial numbers of indigenous peoples (art. 8).

The Paris Agreement signifies the recognition by the international community that climate change poses unacceptable threats to the full enjoyment of human rights and that actions to address climate change must comply with human rights obligations ${ }^{12}$.

As a consequence, it is argued that UNFCCC and the Paris Agreement does not adequately address the magnitude of the threat posed by climate change related harm to human rights. An important implication of the UNFCCC and the Paris Agreement being treaties is that their provisions might, or perhaps in some instances must, take account domestic, regional or international courts in deciding climate cases. Stephen Humphreys famously remarked that the tort-like litigation is likely to be more fruitful in the national than the international context and with regard to past rather than expected harms ${ }^{13}$.

People around the world are turning to national courts to ensure that ambitious action is taken to prevent dangerous climate change. In the United States, the first wave of private climate litigation, corporate defendants

10 Sam Adelman "Human Rights in the Paris Agreement: Too Little, Too Late?", Transnational Environmental Law, 7:1, (2018), 17-36.

11 Annalisa Savaresi “The Paris Agreement: a new beginning?”, Journal of Energy \& Natural Resources Law, 34:1 (2016), 16-26.

12 Oonagh Fitzgerald, Basil Ugochukwu "Imlementing the Paris Agreement: the Relevance of Human Rights to Climate Action. Conference report (February 29, 2016 Toronto, Canada)", 3, May 20, 2019. https://www.cigionline.org/sites/default/files/human_rights_and_climate_change_conference_2016.pdf

13 Stephen Humphreys, "Competing claims: human rights and climate harms", In: Human rights and climate change, ed. Stephen Humphreys, Cambridge University Press, 2009, May 20, 2019, DOI: https://doi.org/10.1017/CBO9780511770722 
managed to prevent several climate change lawsuits from proceeding to the merits stage by challenging the court's jurisdiction through the invocation of the standing and political question doctrines as a first line of defence. ${ }^{14}$ Some of the most famous and noteworthy examples of U.S. climate change litigation is the case of Massachusetts v. United States Environmental Protection Agency ( thereafter - EPA) (2007) ${ }^{15}$. The case was initiated by the petition to the EPA to regulate the emissions of the GHG from new motor vehicles. According to Section 202(a) (1) of the U.S. Clean Air Act, the EPA is under an obligation to regulate air pollutants from new motor vehicles. The U.S. Supreme Court ultimately imposed responsibility for resolving climate change issues on the state authorities in deciding on permitted greenhouse gas emissions regulation and limitation. Another lawsuit, State of Connecticut et al. vs. American Electric Power Company Inc.et al.(2009) was filed by the City of New York and eight federal states against five large U.S. power companies responsible for emitting app. 10\% of all anthropogenic carbon dioxide emissions in the United States ${ }^{16}$. The lawsuit was dismissed by the U.S. District Court stating that the subject matter represented a non-justiciable political question that had to be resolved in the political arena. However, the Second Circuit Court vacated the dismissal and remanded the case stating that the subject claim was not a political question, and ordered further proceedings. In the climate case Comer v. Murphy Oil USA, Inc. (2013) ${ }^{17}$, Ned and Brenda Comer filed against oil, coal and chemical companies for the reasons of their contribution to the increase of GHG emissions, which contributed to the global warming, climate change and eventually to hurricane Katrina, causing injuries, damage to property and the environment, endangering public health, etc. In that case the U.S. District Court also made the decision

14 Geetanjali Ganguly, Joana Setzer, Veerle Heyvaert, "If at First You Don't Succeed: Suing Corporations for Climate Change", Oxford Journal of Legal Studies, 38:4 (2018), 841-868 DOI: https://doi.org/10.1093/ojls/gqy029

15 Case of Massachusetts v. EPA, May 20, 2019 https://supreme.justia.com/cases/ federal/us/549/497/

16 Case of Connecticut et al. vs. American Electric Power Company Inc.et al., May 20, 2019 https://caselaw.findlaw.com/us-2nd-circuit/1105245.html

17 Case of Comer v. Murphy Oil USA, Inc., May 20, 2019 https://caselaw.findlaw. com/us-5th-circuit/1498393.html 
about a political question, but the appellate court determined that the political doctrine issue was not applicable to this particular case and that the plaintiffs had standing as they managed to prove that the injuries and damages suffered were "fairly traceable" to the sued companies' actions. Lawsuits in the second wave of U.S. private climate litigation are already drawing upon the advancements in climate attribution science, and courts might be more open to the notion of individual corporate responsibility for climate harm, provided that partial or contributory causation can be scientifically proven with respect to the defendant's conduct. ${ }^{18}$

EU Countries also witnessed lawsuits concerning climate change filed by their citizens against their governments. In all of these cases, the plaintiffs (either citizens or associations) judicially require the State (or a state agency) to conduct a much stricter climate change policy, especially concerning the level of greenhouse gas (GHG) emissions ${ }^{19}$.

In November 2015 a farmer from the Andean region of Peru Saul Luciano Lliuya appealed to the German court against the German utility company RWE ${ }^{20}$, contending that the company partly contributed to melting a glacier in the Andes Mountains that raised the level of a nearby lake and increased the likelihood of devastating floods to his home and his city of more than 120,000 people and asked for $\$ 20,000$ in compensation to help the local government build a dam for flood control ${ }^{21}$. In 2016 the District Court in Essen dismissed the civil lawsuit against RWE but the Civil High Court in Hamm (Germany) in 2018 rejected the judgment of the Essen Court and selected experts who will decide if the weather is a serious threat of impairment to the plaintiff's property or not (as of the 20 of May 2019)

18 Geetanjali Ganguly, Joana Setzer, Veerle Heyvaert, "If at First You Don't Succeed: Suing Corporations for Climate Change”, Oxford Journal of Legal Studies, 38:4 (2018), 841-868 DOI: https://doi.org/10.1093/ojls/gqy029

19 Pau de Vilchez Moragues, "Broadening the Scope: The Urgenda Case, the Oslo Principles and the Role of National Courts in Advancing Environmental Protection Concerning Climate Change" Spanish yearbook international law, 20(2016), 71-92

20 Saúl versus RWE - The Huaraz Case, May 20, 2019, https://germanwatch.org/en/huaraz

21 Ucilia Wang, "Climate Case by Peruvian Farmer Green-Lighted in Germany”, May 20, 2019, http:/www.climateliabilitynews.org/2017/11/14/climate-change-peru-germany-rwe/ 
The Swiss Federal Supreme Court has a trial Klima Seniorinnen Schweiz v Switzerland ( for the 20 of May of 2019) ${ }^{22}$. According to the lawsuit Klima Seniorinnen Schweiz (Swiss Senior Women for Climate Protection) filed a legal request to four government authorities in Switzerland seeking a "discontinuation of failures in climate protection" in order to ensure that greenhouse gas (GHG) emission reduction targets and measures are at a minimum in line with the Paris Agreement. The senior women allege violations of constitutional principles as well as of human rights enshrined in the Swiss constitution and the European Convention on Human Rights.

The General Court of the European Court of Justice has a lawsuit Carvalho and Others v Parliament and Council (Case T-330/18) ${ }^{23}$. The case has been brought forward by 10 families from Portugal, Germany, France, Italy, Romania, Kenya, Fiji, and the Saami Youth Association Sáminuorra against the EU. Families say that failure of the EU climate policy seriously damages their lives, health and their well-being will be increasingly adversely affected by drought, floods, waves of heat, rising sea levels and disappearance of cold seasons as a result of climate change impact. Specifically, the case argues that the EU's current domestic GHG reduction target, to reduce emissions by $40 \%$ compared to 1990 levels by 2030, is too low to meet the requirements of higher ranking $\mathrm{EU}$ and international laws. There are about 30 judgements (as of the 20th of May of 2019) issued by the European Court of Justice concerning adverse effects of climate change on human rights, which are based on violations of the UNFCCC regulations, Paris Agreement, EU climate law and the Charter of Fundamental Rights of the EU.

As already explained above, the causes for climate cases are diverse, most often ones are those referring to the competent public authority's

22 Cordelia Christiane Bähr, Ursula Brunner, Kristin Casper, Sandra H Lustig, "KlimaSeniorinnen: lessons from the Swiss senior women's case for future climate litigation", Journal of Human Rights and the Environment, 9:2(2018), 194-221, DOI:https:// doi.org/10.4337/jhre.2018.02.04

${ }^{23}$ Carvalho and Others v Parliament and Council, The official website of the Court of Justice in EU, May 20, 2019, http://curia.europa.eu/juris/document/document.jsf?tex$\mathrm{t}=$ climate\%2Btarget \&docid=204870\&pageIndex $=0 \&$ doclang=en\&mode $=$ req \&dir $=\&$ oc$\mathrm{c}=$ first\&part $=1 \& \mathrm{cid}=3165666 \mathrm{Actx} 1$ 
failure to fulfil its obligation to regulate limitations of greenhouse gas (GHG) emissions.

All of the above is a brief outline that climate change can impact on a wide range of human rights which concern organisms and ecosystems, as well as on human systems and well-being. Ignoring the climate change impacts on human rights to environmental conditions of a specified quality (safe, clean, healthy and sustainable environment) is not an option.

\section{HUMAN RIGHTS TO ENVIRONMENTAL CONDITIONS \\ OF A SPECIFIED QUALITY (SAFE, CLEAN, HEALTHY AND SUSTAINABLE ENVIRONMENT) IN UKRAINE}

The interaction between human rights and the climate change regime takes place against the backdrop of how international environmental law and human rights law have interacted over time ${ }^{24}$. For the first time, the human right to environmental conditions of a specified quality (safe, clean healthy and sustainable environment) recognized in the Declaration on the Human Environment approved by countries in 1972 at the United Nations Conference on the Human Environment (Stockholm Conference). The Preamble to the Stockholm Declaration states that the natural and the man-made environment are essential to his well-being and to the enjoyment of basic human life. The first principle of the Stockholm Declaration established the fundamental right of every human to freedom, equality and adequate conditions of life in an environment. In fact, the Stockholm Declaration established the right to an adequate environment, which is one of the fundamental human rights and one of the basic principles of current international environmental law.

Most human rights treaties were drafted and adopted before environmental protection became a matter of international concern. As a result, there are few references to environmental matters in international human rights instruments, although the rights to life and to health are certainly

24 Ellen Hey, Federica Violin, "The Hard Work of Regime Interaction: Climate Change and Human Rights", Paper Annual General Meeting Royal Netherlands Society of International Law, 2018, 1-19 
included and some formulations of the latter right make reference to environmental issues. The African Charter on Human and Peoples` Rights (1981), The Additional Protocol to the American Convention on Human Rights in the area of Economic, Social and Cultural Rights (17 Nov. 1988) and the Rio de Janeiro Declaration on Environment and Development (1992) specified the "human right to favourable environment" in terms of the concept of sustainable development, so that the needs of not only today's, but also future generations in relationships between man and nature etc. were satisfied.

Nowadays human right to specify environmental conditions takes one of the key positions in the system of human rights on the environment, as stated in the UN legal framework of international environment. There are over 500 international treaties and other agreements related to the environment, of which a substantial percentage are multilateral ${ }^{25}$. Over 300 of these agreements have been negotiated since 1972. All international environmental agreements, when considering them in the context of right to specify environmental conditions, are divided into three thematic clusters: firstly, international environmental agreements, where the general principles of cooperation between the states in the field of the environment are defined: the Declaration of Principles, adopted at the United Nations Conference on the Human Environment (1972), the Rio Declaration on Environment and Development (1992), UNECE Convention on Access to Information, Public Participation in Decision-Making and Access to Justice in Environmental Matters (Aarhus, Denmark, 1998); Convention on Environmental Impact Assessment in a Transboundary Context (Espoo, 1992). secondly, international legal acts aimed at the natural resources protection, including parts thereof at risk of extinction: the Convention on the Protection and Use of Transboundary Watercourses and International Lakes (Helsinki, 1992), the Protocol on Water and Health to the Convention on the Protection and Use of Transboundary Watercourses and International Lakes (London, 1999), the Con-

25 Louise Kathleen Camenzuli, The development of international environmental law at the Multilateral Environmental Agreements' Conference of the Parties and its validity, May 20, 2019, https:/www.iucn.org/downloads/cel10_camenzuli.pdf 
vention on the Protection of the Black Sea Against Pollution (Bucharest, 1992) and its Protocols, the Convention on Wetlands of International Importance especially as Waterfowl Habitat (Ramsar, 1971), the Convention on International Trade in Endangered Species of Wild Fauna and Flora (Washington, 1973), the Convention on Biological Diversity (1992), the Cartagena Protocol on Biosafety to the Convention on Biological Diversity (2000), and others;

thirdly, international agreements aimed at ensuring a safe environment, regulation of environmentally hazardous activities and actions in natural and man-made emergencies: the Basel Convention on the Control of Transboundary Movements of Hazardous Wastes and Their Disposal (Basel, 1989), the Convention on the Transboundary Effects of Industrial Accidents (Helsinki, 1992), the Convention on Long-Range Transboundary Air Pollution (Geneva, 1979) Vienna Convention for the Protection of the Ozone Layer (Vienna, 1985), the Montreal Protocol on Substances that Deplete the Ozone Layer (Montreal, 1987) and its protocols as amended, the United Nations Framework Convention on Climate Change (Rio de Janeiro, 1992), the Paris Agreement (Paris, 2015), the International convention relating to intervention on the high seas in cases of oil pollution casualties (Brussels, 1969), the Convention on the Prevention of Marine Pollution by Dumping of Wastes and Other Matter (Moscow, Washington, London, Mexico, 1972), Resolution of the General Assembly of the United Nations No. 56/195 dd. "International Strategy for Disaster Reduction" (2001) and others.

Human rights to environmental conditions of a specified quality are apparent not only in international environmental law, but also in the national environmental legislation adopted by different states. As example, in accordance with art. 50 of the Constitution of Ukraine, the right to adequate environment (the right to a safe and healthy environment) is constitutional. The individual right to a safe and healthy environment is reflected also in the Law of Ukraine "On Environmental Protection", where aforementioned right is among other environmental rights: 1) participation in discussion and submission of proposals for the draft regulatory acts, materials for publication, construction and reconstruction of facilities that may negatively impact the state of environment, submission 
of proposals to the state bodies and local self-government bodies, and legal entities participating in decision-making on these issues; 2) participation in development and implementation of the measures for environmental protection, and natural resources rational and integrated use; 3) general and special natural resources use; 4) association into public environmental protection organizations; 5) free access to environmental information and free information acquisition, use, distribution and storage, except for the limitations established by the law; 6) participation in public discussions on the issue of impact caused by scheduled environmental activities; 7) access to environmental study; 8) lawsuits filing to the state authorities, enterprises, institutions, organizations and citizens on compensation for damage caused to their health and property due to adverse effects on the environment; 9) appeal against decisions, actions or omission to act by state authorities, local self-government bodies and their officials on the citizens' environmental rights violation in accordance with the procedure prescribed by law; 10) participation in the process of strategic environmental impact assessment.

According to the theoretical foundations of the environmental law of Ukraine, within the Ukrainian Environmental Law Scientific School, the right to safety and healthy environment is only one right among "individual environmental rights". In the legal scientific publications in Ukraine reviews individual environmental rights in two aspects, as a subjective and objective category. As a subjective category, environmental rights mean combination of legal opportunities and means aimed at meeting the needs of an individual in natural resources use, environmental protection and environmental safety ${ }^{26}$. N. Kobetska states that environmental rights - is a qualitatively new group of individual rights, which differs from previously existing rights to natural resource management, with primary focus on the satisfaction of environmental, but not material, spiritual and aesthetic needs and interests. The initial point of environmental rights is an ability

26 Volodymyr Andreitsev, Environmental law: lecture course in schemes, Kyiv: Venturi, 1996, 37.; see also Volodymyr Andreitsev, "Ukraine's ecological safety as a component of Ukraine's national safety and a kind of transnational safety: legal aspects" in : Paper Annual Conference National safety of Ukraine, ed.Volodymyr Andreitsev and [others], Dnipro: NGU, 2017,18-25. 
of any individual to use unpolluted environment and to live in an environmentally sound natural habitat ${ }^{27}$.

However, in relation to this, A. Hetman and M. Shulga notes that individual environmental rights have certain unique properties stipulated by environmental factors. They include: 1) individual environmental rights enforcement related to the satisfaction of environmental needs and environmental interests implementation; 2) priority of individual environmental rights in the general system of human rights. It is stipulated by the content of the basic and natural rights to safety and healthy environment; 3) establishing individual environmental rights in the laws of nature, according to which environmental objects are developing; 4) environmental factor determines the forms of natural objects belonging to the relevant subjects; 5) content of environmental rights is stipulated by the principles of environmental law as an independent branch of law; 6) environmental rights are exercised mainly under state control. To ensure environmental rights is the main task of the environmental policy adopted by the state; 7) environmental right features determine the need in choosing optimal and effective legal methods and forms for their protection ${ }^{28}$.

In the legal scientific publications in Ukraine the right to safe and healthy environment is considered as the right to environmental safety ${ }^{29}$. V. Bredikhina has stated, that the human right to environmental safety includes certain basic elements, among which: 1) right to reside or stay in environment safe for human life and health; 2) right to safe quality of natural resources and facilities used to meet citizens ' needs; 3 ) possibility to perform their own legal actions for the right to environmental safety enforcement (for example, free access to information about the state of en-

27 Nadiia Kobetska, Environmental rights of Ukrainian citizens, Kyiv: Institute of State and Law NAS of Ukraine, 1998, 6; see also Nadiia Kobetska, Permitting and contractual regulation of the natural resources use in Ukraine: issues of theory and practice, Ivano-Frankivsk: Vasyl Stefanyk Precarpathian National Unsversity, 2016, 271

${ }^{28}$ Anatolii Hetman, Mykhailo Shulga, Vasil Popov, Environmental Law of Ukraine: textbook for the students of the Higher Institutions of Law, Kharkiv: Publisher "Right". 2005, 67-68. See also Anatolii Hetman, Mykhailo Shulga, Environmental Law of Ukraine: in questions and answers, Kharkiv: Publisher "Right", 2017, 206.

29 Juliia Krasnova, The law of environmental safety: theoretical aspects, Kyiv: NUBiP of Ukraine, 2017, 589 
vironment, quality of food products, participation in public discussions or hearings on the issue of environmentally hazardous facilities construction and operation, etc.); 4) right to demand certain actions to be performed by all obligated persons (including by the state) aimed at this right enforcement and to comply with the rules for environmental safety; 5) right to apply to the relevant authorities (including direct appeal to the court) to protect the right violated; right protection by all legal means (in some cases - self-defence); 6) right to compensation for damage caused by environmental safety right violations ${ }^{30}$.

In practice, such a comprehensive approach will allow systematizing activities of the states in the field of environmental human rights, despite the existing problem in fragmentation ${ }^{31}$ of the international legal regulation, which is related to the fact that own law and order in a particular sphere is often actually established within each environmental convention.

However, the mentioned above right to environmental conditions of a specified quality and others individual environment rights has been established only in the international environmental agreements, but not in the treatment on basic human rights and freedoms, i.e. in the Universal Declaration of Human Rights (1948), European Convention for the Protection of Human Rights and Fundamental Freedoms (1950). Mention Convention does not expressly protect the environment nor does it address environmental issue in any way - it does not provide for any relevant rights in respect of environmental as such. In addition, according to the judicial practice of the European Court of Human Rights, the court considers right to the environmental violations in the context of rights established in the Convention itself. The Strasbourg case law has contributed to the development of certain 'environmental obligations' incumbent

30 Viktoriia Bredikhina, "Basic principles on legal protection provided to the population from the negative impact of environment" in: Legal regulation of environmental safety in Ukraine: textbook, ed. Anatolii Hetman, Mykhailo Shulga, Viktoriia Bredikhina, Kharkiv: Publisher "Right", 2012, 296; see also Viktoriia Bredikhina "Legal Aspects of Implementation of Environmental Imperative in the Field of Nature Use" in Actual problems of ecological, land and agrarian legislation in modern conditions, ed. Anatolii Hetman, Mykhailo Shulga, Kharkiv: Publisher "Right", 2019, 91-94.

31 Marina Medvedieva, "International "environmental" disputes and fragmentation of the international environmental law", The Journal "European Initiative" 1(2011) 180-187. 
upon states parties by virtue of the Convention ${ }^{32}$. These include the obligation: 1) to regulate activities of an industrial or technological nature which might be adverse to the right to life (Article 2) and the right to private and family life (Article 8); 2) to enforce legal, administrative, or judicial measures designed to prevent or remedy the unlawful interference with such rights(Article 6); 3) to provide information and engage in consultation with affected individuals and people with regard to the actual risk and danger of the environmental impact in issue (Article 10); 4) to the peaceful enjoyment of his possessions (Article 1 Protocol to the Convention for the Protection of Human Rights and Fundamental Freedoms). Some of the main human rights treaties also have specific environmental provisions, usually phrased in relatively narrow terms focused on human health ${ }^{33}$. Dinah Shelton provides that human rights tribunals have given effect to various human rights linked to environmental protection by reference to international environmental principles, standards and norms ${ }^{34}$. In addition, they have emphasized the importance of giving effect to national environmental rights provisions.

\section{CONCLUSION}

It is clear today that climate change is interfering with the enjoyment of several human rights such as right to live, right to health, right to food, property and so on. Climate change also has a huge impact to the human right to environmental conditions of a specified quality (safe, clean, healthy and sustainable environment).

For the first time the issues of interaction between climate change and human rights were raised in international resolutions, decisions and reports, focuses on the main human rights treaty bodies: the UN Human Rights Council, and the UN Intergovernmental Panel on Climate Change

32 Francesco Francioni, "International Human Rights in an Environmental Horizon”, European Journal of International Law, 21:1 (2010) 41-55.

33 Alan Boyle, "Human Rights and the Environment: Where Next?", European Journal of International Law, 23: 3 (2012) 613-642.

34 Shelton Dinah L., "Developing Substantive Environmental Rights", Journal of Human Rights and the Environment, 1:1, (2010) 89-120. 
and by the Conference of the Parties to the United Nations Framework Convention on Climate Change (UNFCCC). Unfortunately, the UN Climate Change International Legal Regime does not adequately address the magnitude of the threat posed by climate change related harm to human rights but it is the basis for the citizens of different countries appeal to the international and national courts seeking protection of their rights from climate changes impact.

Human right to environmental conditions of a specified quality (safe, clean, healthy and sustainable environment) is one of the fundamental human rights that needs protection from the impact of climate change. More than 200 multilateral international environmental agreements signed at different times within the UN and other international organizations aimed at protecting rational natural use and ensuring environmental safety of various components of environment and such components as climatic system, in the sense of the UNFCCC, have been approved and implemented up to date. International environmental agreements demonstrate the capacity of the human rights system to interpret laws aimed to prevent dangerous impact of climate change. The list of international environmental agreements can be significantly extended, but current environmental challenges in society and natural environment development in the context of global climate changes requires discussion of the effectiveness of international legal mechanisms and activities of the states in terms of their implementation.

\section{REFERENCES:}

An IPCC Special Report on the impacts of global warming of $1.5^{\circ} \mathrm{C}$ above pre-industrial levels and related global greenhouse gas emission pathways, in the context of strengthening the global response to the threat of climate change, sustainable development, and efforts to eradicate poverty" May 20, 2019 https://report.ipcc.ch/sr15/pdf/sr15_spm_final.pdf

Human Rights Council Resolution 7/23 May 20, 2019 http://ap.ohchr.org/documents/E/HRC/resolutions/A_HRC_RES_7_23.pdf

Human Rights Council Resolution 10/4 May 20, 2019 https://ap.ohchr.org/ documents/E/HRC/resolutions/A_HRC_RES_10_4.pdf 
David R. Boyd, "Statement on the human rights obligations related to climate change, with a particular focus on the right to life" May 20, 2019 https:// www.ohchr.org/Documents/Issues/Environment/FriendsIrishEnvironment25Oct2018.pdf

An IPCC Report "Climate Change 2014 Impacts, Adaptation, and Vulnerability Part A: Global and Sectoral Aspects”, May 20, 2019 https://www.ipcc.ch/ site/assets/uploads/2018/03/ar5_wgII_spm_en-1.pdf

Human Rights Council Resolution 38/4 May 20, 2019 https://documents-dds-ny. un.org/doc/UNDOC/LTD/G18/201/26/PDF/G1820126.pdf?OpenElement

Case of Massachusetts v. EPA May 20, 2019 https://supreme.justia.com/cases/ federal/us/549/497/

Case of Connecticut et al. vs. American Electric Power Company Inc.et al. May 20, 2019 https://caselaw.findlaw.com/us-2nd-circuit/1105245.html

Case of Comer v. Murphy Oil USA, Inc. May 20, 2019 https://caselaw.findlaw. com/us-5th-circuit/1498393.html

Saúl versus RWE - The Huaraz Case May 20, 2019 https:/germanwatch.org/en/ huaraz

Carvalho and Others v Parliament and Council, The official website of the Court of Justice in EU May 20, 2019, http://curia.europa.eu/juris/document/ document.jsf?text=climate $\% 2$ Btarget $\&$ docid $=204870 \&$ pageIndex $=0 \&$ doclang $=$ en \&mode $=$ req \&dir $=\& o c c=$ first $\&$ part $=1 \&$ cid $=3165666 \#$ ctx 1

Adelman Sam, 2018, Human Rights in the Paris Agreement: Too Little, Too Late?, Transnational Environmental Law, 7:1.

Andreitsev Volodymyr, 1996, Environmental law: lecture course in schemes, Kyiv:Venturi.

Andreitsev Volodymyr, 2017, "Ukraine's ecological safety as a component of Ukraine's national safety and a kind of transnational safety: legal aspects" in : Paper Annual Conference National safety of Ukraine, ed. Volodymyr Andreitsev and [others],18-25, Dnipro: NGU.

Bähr Cordelia Christiane, Brunner Ursula, Casper Kristin, Lustig, Sandra H, 2018, "KlimaSeniorinnen: lessons from the Swiss senior women's case for future climate litigation", Journal of Human Rights and the Environment, 9:2, DOI: https://doi.org/10.4337/jhre.2018.02.04

Boyle Alan, 2012, Human Rights and the Environment: Where Next?, European Journal of International Law, 23:3.

Bredikhina Viktoriia, 2012, "Basic principles on legal protection provided to the population from the negative impact of environment" in: Legal regulation of environmental safety in Ukraine: textbook, ed. Anatolii Hetman, Mykhailo Shulga, Viktoriia Bredikhina, 17-62, Kharkiv: Publisher "Right". 
Bredikhina Viktoriia, 2019, "Legal Aspects of Implementation of Environmental Imperative in the Field of Nature Use" in Actual problems of ecological, land and agrarian legislation in modern conditions, ed. Anatolii Hetman, Mykhailo Shulga, 91-94, Kharkiv: Publisher "Right".

Camenzuli Louise Kathleen, "The development of international environmental law at the Multilateral Environmental Agreements' Conference of the Parties and its validity" May 20, 2019 https://www.iucn.org/downloads/cel10_ camenzuli.pdf

Dinah L. Shelton, 2010, “Developing Substantive Environmental Rights”, Journal of Human Rights and the Environment, 1:1.

Fitzgerald Oonagh, Ugochukwu Basil "Implementing the Paris Agreement: The Relevance of Human Rights to Climate Action. Conference report (February 29, 2016 Toronto, Canada)" May 20, 2019 https://www.cigionline.org/sites/default/files/human_rights_and_climate_change_conference_2016.pdf

Francioni Francesco, 2010, International Human Rights in an Environmental Horizon in: European Journal of International Law, 21:1.

Ganguly Geetaniala, Setzer Joanna, Heyvaert Veerle, 2018, "If at First You Don't Succeed: Suing Corporations for Climate Change", Oxford Journal of Legal Studies, 38:4 DOI: https://doi.org/10.1093/ojls/gqy029

Hey Ellen, Violi Federica, 2018, The Hard Work of Regime Interaction: Climate Change and Human Rights, Paper Annual General Meeting Royal Netherlands Society of International Law.

Hetman Anatolii, Shulga Mykhailo, Popov Vasil, 2005, Environmental Law of Ukraine: Textbook for the students of the Higher Institutions of Law, Kharkiv:Publisher "Right".

Hetman Anatolii, Shulga Mykhailo, 2017, Environmental Law of Ukraine: in questions and answers, Kharkiv: Publisher "Right".

Humphreys Stephen, 2009, "Competing claims: human rights and climate harms", In: Human rights and climate change, ed. Stephen Humphreys, Cambridge University Press.

Kobetska Nadiia, 1998, Environmental rights of Ukrainian citizens, Kyiv: Institute of State and Law NAS of Ukraine.

Kobetska Nadiia, 2016, Permitting and contractual regulation of the natural resources use in Ukraine: issues of theory and practice, Ivano-Frankivsk: Vasyl Stefanyk Precarpathian National Unsversity.

Krasnova Juliia, 2017, The law of environmental safety: theoretical aspects, Kyiv.: NUBiP of Ukraine. 
Lewis Bridget, 2018, Environmental Human Rights and Climate Change. Current Status and Future Prospects, Singapore: Springer.

Moragues Pau de Vilchez, 2016, Broadening the scope: The Urgenda case, the Oslo Principles and the role of national courts in advancing environmental protection concerning climate change, Spanish yearbook international law, 20

Medvedieva rina, 2011, International "environmental" disputes and fragmentation of the international environmental law, The Journal "European Initiative", Kyiv.

Savaresi Annalisa, 2016, The Paris Agreement: A New Beginning?, Journal of Energy \& Natural Resources Law, 34(1).

Wang Ucilia, "Climate Case by Peruvian Farmer Green-Lighted in Germany" May 20, 2019 http://www.climateliabilitynews.org/2017/11/14/climatechange-peru-germany-rwe/ 